\title{
CONTENTS
}

\section{Breeding and genetics}

Mormède, P., Foury, A., Terenina, E. and Knap, P. W.

Breeding for robustness: the role of cortisol (review)

Leisson, K., Alev, K., Kaasik, P., Jaakma, Ü. and Seene, T.

Myosin heavy chain pattern in the Akhal-Teke horses

Magnol, L., Monestier, O., Vuillier-Devillers, K., Wagner, S., Cocquempot, O., Chevallier, M. C. and Blanquet, V.

A sensitised mutagenesis screen in the mouse to explore the bovine genome: study of muscle characteristics

Boysen, T. J., Tetens, J. and Thaller, G.

Evidence for additional functional genetic variation within the porcine IGF2 gene affecting body composition traits in an experimental Piétrain $\times$ Large White/Landrace cross

Nutrition

Kraft, G., Ortigues-Marty, I., Durand, D., Rémond, D., Jardé, T., Bequette, B. and Savary-Auzeloux, I.

Adaptations of hepatic amino acid uptake and net utilisation contributes to nitrogen economy or waste in lambs fed nitrogen- or energy-deficient diets

Huhtanen, P., Rinne, M., Mäntysaari, P. and Nousiainen, J.

Integration of the effects of animal and dietary factors on total dry matter intake of dairy cows fed silage-based diets

Physiology and functional biology of systems

Rehfeldt, C., Te Pas, M. F. W., Wimmers, K., Brameld, J. M., Nissen, P. M., Berri, C., Valente, L. M. P.,

Power, D. M., Picard, B., Stickland, N. C. and Oksbjerg, N.

Advances in research on the prenatal development of skeletal muscle in animals in relation to the quality

of muscle-based food. I. Regulation of myogenesis and environmental impact (review)

Rehfeldt, C., Te Pas, M. F. W., Wimmers, K., Brameld, J. M., Nissen, P. M., Berri, C., Valente, L. M. P.,

Power, D. M., Picard, B., Stickland, N. C. and Oksbjerg, N.

Advances in research on the prenatal development of skeletal muscle in animals in relation to the quality of

muscle-based food. II - Genetic factors related to animal performance and advances in methodology (review)

Cutullic, E., Delaby, L., Gallard, Y. and Disenhaus, C.

Dairy cows' reproductive response to feeding level differs according to the reproductive stage and the breed

van der Waaij, E. H., van den Brand, H., van Arendonk, J. A. M. and Kemp, B.

Effect of match or mismatch of maternal-offspring nutritional environment on the development of offspring

in broiler chickens

Chaosap, C., Parr, T. and Wiseman, J.

Effect of compensatory growth on performance, carcass composition and plasma IGF-1 in grower finisher pigs

Behaviour, welfare and health

Herskin, M. S., Bonde, M. K., Jørgensen, E. and Jensen, K. H.

Decubital shoulder ulcers in sows: a review of classification, pain and welfare consequences (review)

Zonderland, J. J., Schepers, F., Bracke, M. B. M., den Hartog, L. A., Kemp, B. and Spoolder, H. A. M.

Characteristics of biter and victim piglets apparent before a tail-biting outbreak

Matheson, S. M., Rooke, J. A., Mcllvaney, K., Jack, M., Ison, S., Bünger, L. and Dwyer, C. M.

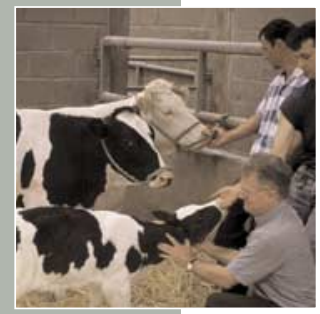

Development and validation of on-farm behavioural scoring systems to assess birth assistance and lamb vigour

Farming systems and environment

McCarthy, B., Delaby, L., Pierce, K. M., Journot, F. and Horan, B.

Meta-analysis of the impact of stocking rate on the productivity of pasture-based milk production systems

Product quality, human health and well-being

Peiretti, P. G., Masoero, G. and Meineri, G.

Effects of replacing palm oil with maize oil and Curcuma longa supplementation on the performance, carcass characteristics, meat quality and fatty acid profile of the perirenal fat and muscle of growing rabbits

Bispo, E., Moreno, T., Thomas, A., Durand, D., Monserrat, L., Gonzalez, L. and Bauchart, D.

Effects of weaning and finishing feeding treatment on fatty acids, especially cis and trans C18:1 isomers,

in the Longissimus thoracis muscle of Galician Blond calves

Werner, $C$., Janisch, S. and Wicke, $M$.

Mitochondrial respiratory and antioxidative enzyme activities in broiler meat in relation to age and gender of the animals

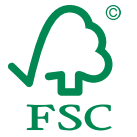
1996 Forest Stewardship Council 


\section{Advertise in \\ Cambridge Journals}

To advertise in this journal and for details of pricing, availability and discount opportunities please contact:

\section{Advertise here}

With over 250 titles to choose from With over 250 tist of journals ensures our extensive list of jour suitable you will always find your suitable target audience. Our journals over 32 subject areas, ranging from Agriculture. Archaeology and Anthropology, Nutrition, to Psychology and Cognitive Science, Religion and inserts Social Studies. Print advertising, inserts and banner advertising are majority of our titles.

Cacess Cambridge loumals please visit: To access Cambridge sambridge.org journals.cambiog

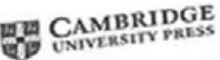

Advertising in UK, Europe and Rest of World

The Advertising Sales Team Cambridge University Press

The Edinburgh Building,

Shaftesbury Road,

Cambridge, UK, CB2 8RU

Tel: +44 (0) 1223325083

Email: ad_sales@cambridge.org

Advertising in USA, Mexico and Canada

Journals Advertising Coordinator 32 Avenue of the Americas,

New York, NY 10013-2473, USA

Tel: +1 (212) 3375053

Fax: +1 (212) 3375959

Email:

journals_advertising@cambridge.org 


\section{CAMBRIDGE JOUNALS}

\section{World's Poultry Science Journal}

Published on behalf of

The World's Poultry Science Association

\section{Editor}

Lucy Waldron, LWT Animal Nutrition Ltd, New Zealand

World's Poultry Science Journal provides authoritative reviews in poultry science and an international forum for the exchange and dissemination of information including research, education and industry organisation. Each issue includes poultry industry-related news, regional reports on global developments in poultry, reports from specialist scientific working groups, book reviews, association news and a calendar of forthcoming events.

Coverage includes breeding, nutrition, welfare, husbandry, production systems, processing, product development, physiology, egg and meat quality, industry structure, economics and education.

The journal is of interest to academics, researchers, students, extension workers and commercial poultry producers.

Submit your research online http://mc.manuscriptcentral.com/wpsj

For free online content visit: http://journals.cambridge.org/wpssample

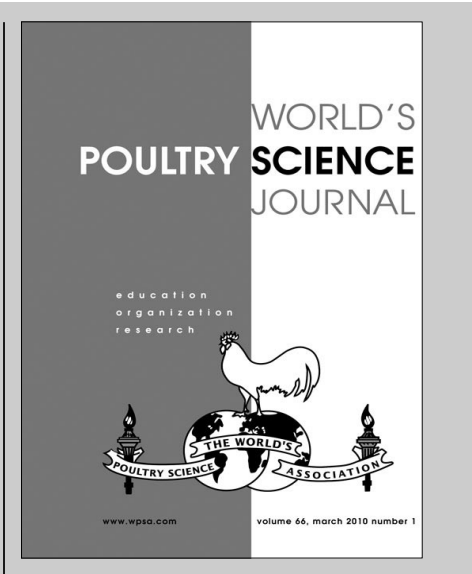

World's Poultry Science Journal is available online at: http://journals.cambridge.org/wps

\section{To subscribe contact}

Customer Services

Americas:

Phone +1 (845) 3537500

Fax +1 (845) 3534141

Email

subscriptions_newyork@cambridge.org

\section{Rest of world:}

Phone $+44(0) 1223326070$

$\mathrm{Fax}+44(0) 1223325150$

Email journals@cambridge.org

\section{Free email alerts}

Keep up-to-date with new content

http://journals.cambridge.org/wps-alerts 


\section{CAMBRIDGE JULNALS}

\section{Journal of Agricultural Science}

\section{Senior Editor (Animal papers) \\ Julian Wiseman, University of Nottingham, UK Senior Editor (Crop \& Soil papers) \\ Robert E. L. Naylor, Robert E. L. Naylor}

The Journal of Agricultural Science publishes papers concerned with the advance of agriculture and the use of land resources throughout the world. It publishes original scientific work related to strategic and applied studies in all aspects of agricultural science and exploited species, as well as reviews of scientific topics of current agricultural relevance.

The Journal of Agricultural Science publishes papers concerned with the advance of agriculture and the use of land resources throughout the world. It publishes original scientific work related to strategic and applied studies in all aspects of agricultural science and exploited species, as well as reviews of scientific topics of current agricultural relevance.

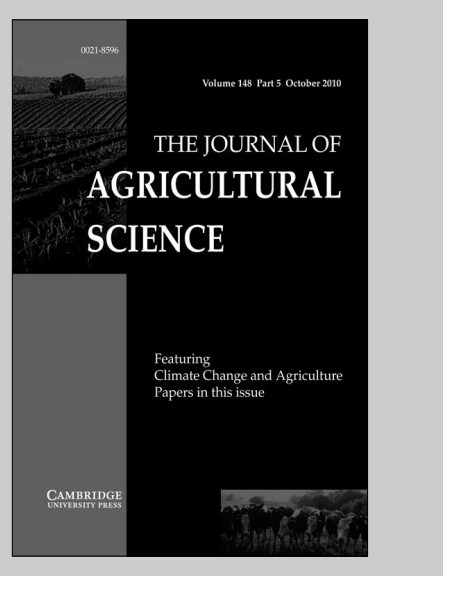

Journal of Agricultural Science is available online at:

http://journals.cambridge.org/ags

To subscribe contact

Customer Services

Americas:

Phone +1 (845) 3537500

Fax +1 (845) 3534141

Email

subscriptions_newyork@cambridge.org

\section{Rest of world:}

Phone +44 (0)1223 326070

$\mathrm{Fax}+44(0) 1223325150$

Email journals@cambridge.org

Free email alerts

Keep up-to-date with new material - sign up at

journals.cambridge.org/register

For free online content visit: http://journals.cambridge.org 


\section{CAMBRIDGE JOURNALS}

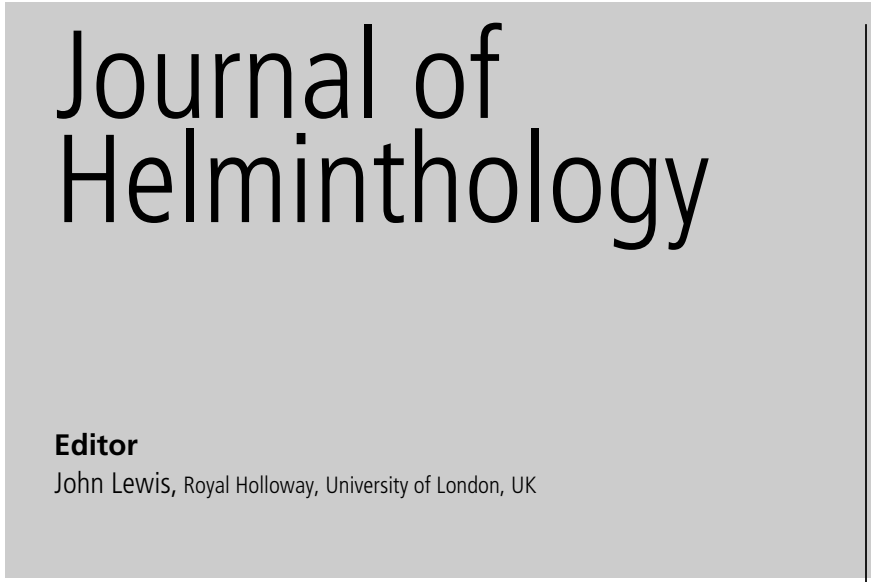

Journal of Helminthology publishes original papers and review articles on all aspects of pure and applied helminthology, particularly those helminth parasites of environmental health, medical or veterinary importance. Research papers on helminths in wildlife hosts, including plant and insect parasites, are also published along with taxonomic papers contributing to the systematics of a group. The journal will be of interest to academics and researchers involved in the fields of human and veterinary parasitology, public health, microbiology, ecology, epidemiology and biochemistry.

\section{Price information}

is available at: http://journals.cambridge.org/jhl

\section{Free email alerts}

Keep up-to-date with new material - sign up at http://journals.cambridge.org/jhl-alerts

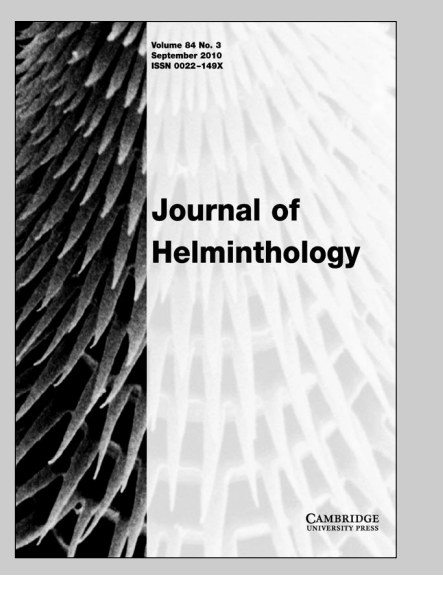

Journal of Helminthology is available online at: http://journals.cambridge.org/jhl

To subscribe contact Customer Services

in Cambridge:

Phone $+44(0) 1223326070$

Fax $+44(0) 1223325150$

Email journals@cambridge.org

in New York:

Phone +1 (845) 3537500

$\mathrm{Fax}+1$ (845) 3534141

Email

subscriptions_newyork@cambridge.org

For free online content visit: http://journals.cambridge.org/jhl 